\title{
The Mediating Effect of Crisis Management on Leadership Styles and Hotel Performance in Jordan
}

\author{
Raed Hussam Alzoubi ${ }^{1} \&$ Amar Hisham Jaaffar ${ }^{2}$ \\ ${ }^{1}$ College of Graduate Studies, Universiti Tenaga Nasional, Malaysia \\ ${ }^{2}$ College of Business Management and Accounting, Universiti Tenaga Nasional, Malaysia \\ Correspondence: Raed Hussam Alzoubi, PhD Student at Universiti Tenaga Nasional, Putrajaya Campus, Jalan \\ IKRAM-UNITEN, 43000 Kajang, Selangor, Malaysia.
}

Received: March 30, 2020

doi:10.5430/ijfr.v11n4p384
Accepted: May 16, 2020

Online Published: July 7, 2020

URL: https://doi.org/10.5430/ijfr.v11n4p384

\begin{abstract}
Research scholars have argued that the emergence of the crisis in the Middle East have led to significant changes in business performance. This has been most notable in the hotels operating in the Jordanian tourist sector, thus, creating a need to investigate leadership styles, crisis management, and hotel performance in a holistic framework. However, this is quite lacking in the literature, and this needs to be addressed. Transformational leadership style and transactional leadership styles are the independent variables, crisis management is the mediating variable and hotel performance is the dependent variable. A quantitative study that used a self-administered questionnaire was carried out on 3-star to 5-star hotels operating in Jordan. The Partial Least Squares (PLS) method as part of Structural Equation Modelling (SEM) was applied to analyse the causal relationships between constructs using the software application Smart-PLS 3.0. The Partial Least Squares approach was chosen according to the research's exploratory nature. In order to analyze data two-step approach was utilized; the first step was to test the reliability and validity of the constructs in the measurement models, the second step was to test research hypotheses in the structural models. The results show that transformational leadership has significant positive effects on hotel performance and crisis management. Transactional leadership had a significant positive effect on crisis management and crisis management had significant positive effects on hotel performance. Moreover, crisis management partially mediated the relationship between transformational leadership and hotel performance; while the relationship between transactional leadership and hotel performance was fully mediated by crisis management. These findings will help to strengthen the discussion in the extant literature.
\end{abstract}

Keywords: crisis management, tourism, hotel performance, transactional leadership, transformational leadership, mediating effect

\section{Introduction}

Since December 2010, revolutionary waves took place in many Arab countries and were presented in the media as the "Arab Spring"; protests took place in Tunisia and Egypt and shortly after emerged in Middle Eastern region. Jordan was severely affected by this situation. Many visitors from Europe and America cancelled their visits, a reduction was experienced in tourist arrivals from 8,078,380 tourists in 2010 to $6,812,438$ tourists in 2011 (15.7\% decrease); while the number of package tours decreased from 707,735 to 419,571 (Ministry of Tourism \& Antiquities [MOTA], 2011). Other notable examples of crisis occurrence that hampered crisis recovery and affected tourists' arrivals in Jordan include; the suicide bombing that took place in 2005 in Radisson hotel in Amman, Jordan (Fattah \& Slackman, 2005). Moreover, Jordan is facing the challenge of dealing with spillover effect caused by instability in surrounding countries, also the economic, political and social pressure caused by receiving big numbers of Syrian refugees (UNWTO, 2017).

The hotel sector is very vital to Jordanian tourism (Al-Omari, et al., 2015). As a result of the negative image portrayed by the Middle East crisis, Jordan tourism potentials have been impacted negatively (Masa'deh, Alananzeh, Tarhini, \& Algudah, 2018). More so, lately, tourism in Jordan has experienced some changes and the hotels are showing some form of stagnancy. Based on these issues, current challenges have arisen in the hotel sector in Jordan. Accordingly, the Jordanian government instituted the National Strategy for Tourism which seeks to rebrand the tourism potential of Jordan in the ace of negative image occasioned by the Middle East crisis. This places the onus 
researchers to offer vital findings that will achieve the lofty objectives of this governmental initiative.

Crisis management as an avenue for destination image rebranding in the tourism industry has been noted to be an important issue as reported in some western parlance. Nevertheless, some developing countries, as well as many developing countries haven't received the desired research attention in spite of the fact that destination image is a significant determinant in making travel decisions (Schneider \& Sönmez, 1999; Aigbogun, Yassin, \& Zeeshan, 2013). Worse still, due to the crisis in several Middle Eastern countries, it is imperative that research efforts be channeled into crisis management in this context. There is a challenge in ascertaining whether organizational leadership styles influence the performance of hotels operating in the tourism sector in Jordan (Al-Ababneh \& Lockwood, 2010). This is due to the fact that at present, the volatility in the external business environment has exposed firms to face threats from a wide range of risks leading to a crisis in the present-day economic and socio-political environment in Jordan. This thus requires a change in strategy. However, the question is; do leadership styles affect crisis management, as well as the performance of hotels in the tourism sector of Jordan? This paper embodies an examination of the effect of leadership styles on hotel performance and an evaluation of the intermediation of crisis management in this relationship.

\section{Literature Review}

A number of studies have been carried out on leadership styles and its impact in sustaining organizational performance. However, not may have focused on the hotel sector, which in itself presents unique characteristics distinct from other types of organizations. Moreover, the effect crisis management has on this in a holistic framework has had limited discussion in the literature, hence the significance of this study. This section presents a brief review of previous studies.

\subsection{Crisis Management}

Santana (1999) defines crisis management as a continuous and holistic effort that organizations efficiently carry out in order to understand and prevent a crisis, as well as to manage those that arise, putting into consideration the interest of stakeholders (p. 286). Spillan and Hough (2003) defines crisis management as the purpose that works on minimizing the influence of a crisis and supports an organization to gain control. It also functions to get advantage of the benefits presented by crisis (p. 401). Whereas crisis management is defined by Coombs (2015) as a group of factors planned to defeat crises and to reduce the damage caused by it (p. 36).

According Wahbeh (2008) crisis management entails the making of strategic decisions to sidestep an avoidable potential risk event/threat or to bounce back from an unavoidable threat/risk event that could have a negative effect on business continuity. In the Middle Eastern context, crisis management studies have been carried out mainly among the state of the banking industry. For instance, Al Hanafi (2007) in his study, crisis management was grounded on the examination of potential threats, followed by the formulation of strategies to mitigate the effect of the potential threats in the Iraqi banking industry. However, drawing from the literature in emergency preparedness, the study carried out by Mitroff (1988) suggested a five-phase holistic model of crisis management. This model has been adopted and widely used by research scholars.

The five phases of the model of crisis management are; crisis signal detection, crisis preparation, crisis containment, crisis recovery, and crisis learning. Hensgen, Desouza, and Kraft (2003) enriched the five-staged model of crisis management model of Mitroff (1988) by inputting the essentials of chaos as well as stress with more attention to the crisis signal detection stage of the model; due to the fact that the authors believe that the crisis signal phase of the five-staged model for crisis management is often ignored or limited attention is paid to this phase, hence limiting the overall crisis management intervention. This five-staged model of crisis management model of Mitroff (1988) has been successfully applied to different studies, an example is the study of Chowdhury and Quaddus (2016) in the apparel industry of Bangladesh via a quantitative research method applying a self-administered designed type questionnaire directly to the research target population which was made up of supply chain managers. In their study, the resilience which is conceptualized as the best crisis management approach for supply chains was conceptualized in the form of Mitroff (1988) model for crisis management making up the measurement dimensions for resilience in Chowdhury and Quaddus (2016) study. The findings from their study validates the dimensions of crisis signal detection, crisis preparation, crisis containment, crisis recovery and crisis learning. Also, the findings of the study showed that the culture of the supply chain risk management (mediating variable) fully mediated the relation between the orientation of supply chain (independent variable) and the dependent variable - crisis management conceptualized as supply chain resilience (preparation, containment, recovery and learning).

In their study Yu, Stafford, and Armoo (2005) propose that crisis management must comprise of crisis preparation, 
crisis containment and crisis recovery. Ping, Cui, and Pan (2011) adapted their study on crisis management to three stages (preparation, recovery, and response). Coombs (2015) argues that crisis management includes four main factors: Prevention, preparation, response and revision. There are three-stage approach explaining crisis management as including three phases that incorporate these factors. The first one is the pre-crisis phase (prevention and preparation), the second is the crisis phase (response), and the third is the post-crisis phase (learning and revision). Coombs and Laufer (2018) claimed that crisis management consists of the same phases mentioned previously. According to Alkhawlani, et al. (2016) as well as Aljuhmani and Emeagwali (2017), crisis management is classified as Crisis signal detection, Crisis preparation, Crisis containment, Crisis recovery and Crisis learning.

\subsection{Leadership Styles and Crisis Management in Hotel Industry}

Even though the influence of leadership styles on crisis management has been well discussed and documented in the literature, there is a need for specific studies in the tourism industry involving hotel businesses. More so, a vital need for studies that would evaluate how the leadership styles affect key crisis management dimensions such as those applied in the current study (crisis signal detection, crisis preparation, crisis containment, crisis recovery, and crisis learning).

Crisis management requires effective leadership criteria represented in strong communication with stakeholders and external parties, decision-making, ability to assure the public, active advocacy, effective delegation and coordination of resources and response, to have available and involved leaders who can stimulate good partnership with stakeholders (Aigbogun, Ghazali, \& Razali, 2015; Kharabsheh et al, 2017; Arifah, Tariq, Rosliza, \& Juni, 2018; Alzoubi \& Jaaffar, 2020).

Another important role leadership in crisis conditions plays in the hotels sector is that it copes with unpredicted situations and limited decision time in addition to the limited reaction time. Thus, resource allocation in the occurred crisis includes financial and human resources (Zech, 2014). The main element determining the leadership style to be applied is the task structure and demand for the given situation (Parrotto \& Kim, 2018). According to Ritchie (2009), crisis planning at any level benefits from a group decision support, where decision-makers learn from each other as a result. On the other hand, Quist (2001) assumed that the more an issue is perceived to be a crisis, the greater the centralization of authority by top-level decision-makers in tasks related to the issue.

Zech (2016) argues that brainstorming and distinguished input help in achieving the added value depending on strategic findings of the individual. Which means, during crisis management strategy process the whole team (employees and management) must be included. All group members will not be able to be included by the crisis response management because of reaction time limitations in a consensus-driven decision-making procedure. Tsai (2008) noted that the industry of hotels plays a vital part in the tourism industry, as a result, it has to constantly improve its services delivery and competitiveness. Since the employees of every hotel are essential in the service quality delivery, they are thus important in crisis management. The employees are directly affected by the leadership styles adopted in their organization's managers. Hence employee motivation affects the implementation of crisis management strategies in the times of crisis occurrence.

\subsection{Crisis Management and Hotel Performance}

Yu, Stafford, and Armoo (2005) suggest three aspects that hotels must consider when developing a plan for crisis management: (i). To highly understand how crises affect the tourist industry, and how different organizations respond to and recovered from; (ii). A great awareness of expected conditions that could lead to upcoming crises throughout its membership; (iii). Crisis response and recovery must be carefully defined accordingly connected to the plan of the larger society crisis management.

Zech (2014) came up with a conclusion that organizations can recover from the crisis by processing formation rapidly, taking immediate stages, being constant as well as updating reservations, distributing hotline information, press releases, making action communications. All actions of crisis management must consider the relationship approach of the stakeholder starting with internal stakeholder (Employees and Managers). Rousaki and Alcott (2006), claim the first facet of crisis readiness is the internal functionality of the organization. This suggests that to design a promising network all home works of participating entities have to be done; own duties are not implied to be transferred by the stakeholder related crisis management.

Laws and Prideaux (2013) surveyed hotel managers in the USA about the impact of crisis management strategies on the performance of their hotels. Their findings underscored the positive impact of devising proactive crisis management for future crisis events. Moreover, in research applied by Aldehayyat et al. (2011) to examine the link between the utilization of strategic planning tools as well as strategic techniques and managers' notions of the 
strategic planning process in Jordanian hotels, a number of insights were observed. Firstly, the findings indicate that Jordanian hotels are more inclined towards external analysis relative to internal analytical factors like internal capability, previous performance and also reasons for previous failures. Secondly, the findings of the study also revealed that analysis of the external environment is not enough for a firm to attain a competitive advantage over others. The results of Mohammad et al. (2014) show that crisis management has a significant positive influence on the innovation performance of five-star hotels in Jordan.

By means of a structured type questionnaire Al-Omari et al. (2015) in their research on the influence of the Arab Spring socio-political crisis on hotel sector in Jordan, surveyed 200 hotels doing business in Amman. They analyzed the primary data gathered by means of measures of central tendencies as well as a one-way ANOVA. The findings from their study indicated that the Arab spring socio-political crisis negatively affected the Jordanian hotel sector. This was evident in three extents hotel occupation rates, number of nights spent by patrons as well as hotel revenues. Due to this impasse, the authors acknowledged that studies are required to develop workable models that aids the management of this crisis. It is a matter of concern however that no research-based study till date has been carried out to fill this gap in knowledge. Hence the significance of the current study.

\section{Conceptual Model and Research Hypotheses}

The conceptual model (Table) is intended to test 5 research hypotheses (Table 1) related to the direct effects of Transformational Leadership (TFL), Transactional Leadership (TSL), and Crisis Management (CSM) on Hotel Performance (HTP) representing hypotheses H1, H2, H3, H4 and H5 respectively. Moreover, the Hypotheses H6 and $\mathrm{H} 7$ refer to the mediation effects of Crisis Management (CSM) on the relationship between Transformational Leadership (TFL) and Transactional Leadership (TSL) as independent variables on Hotel Performance (HTP) as dependent variable.

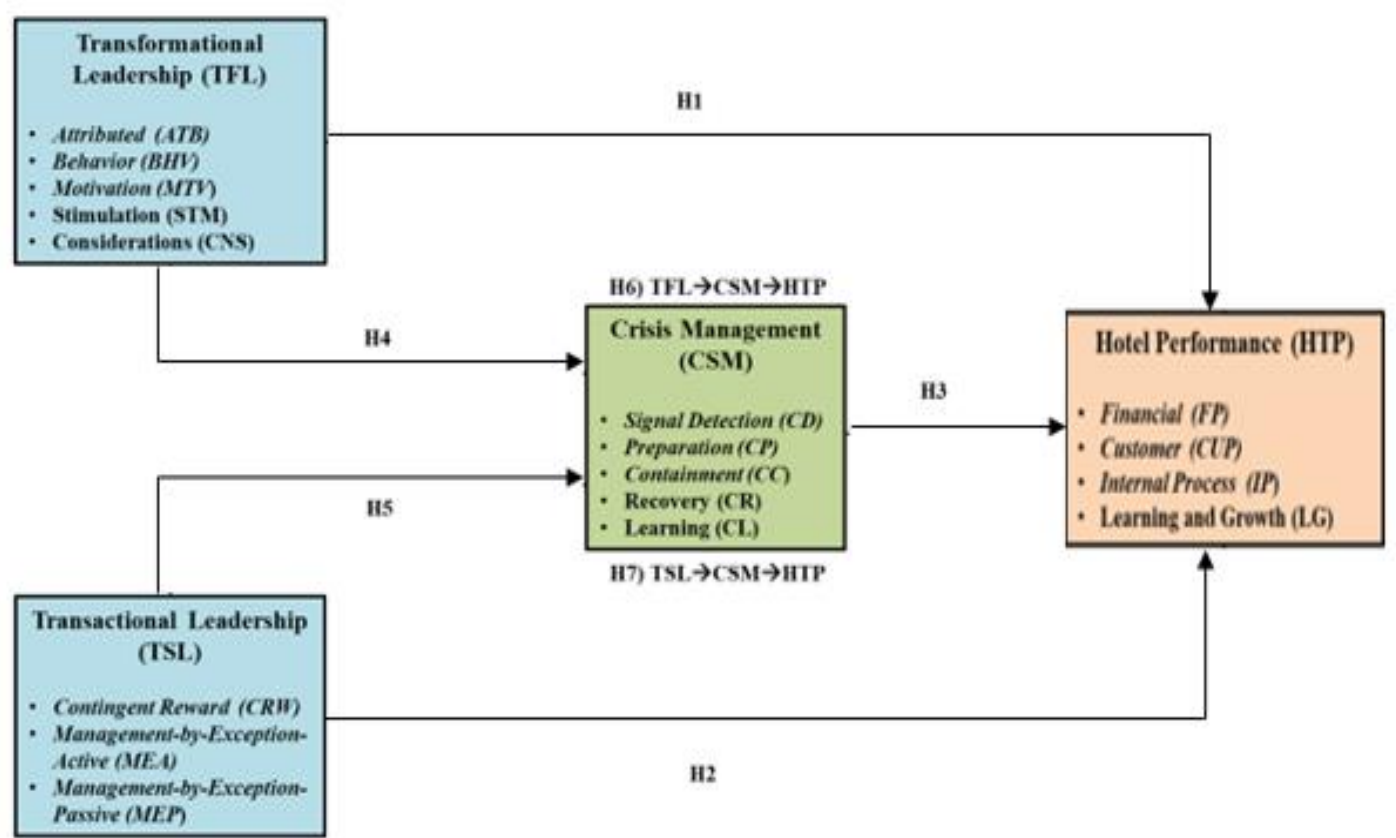

Figure 1. Conceptual model

Table 1. Hypotheses (Codes and descriptions)

\begin{tabular}{lll}
\hline Code & Description & Path \\
\hline Direct Effect Hypotheses & \\
\hline H1 & Transformational Leadership (TFL) has positive effect on Hotel Performance (HTP) & TFL $\rightarrow$ HTP \\
H2 & Transactional Leadership (TSL) has positive effect on Hotel Performance (HTP) & TSL $\rightarrow$ HTP
\end{tabular}


H3 Crisis Management (CSM) has positive effect on Hotel Performance (HTP)

$\mathrm{CSM} \rightarrow \mathrm{HTP}$

H4

Transformational Leadership (TFL) has positive effect on Crisis Management

$\mathrm{TFL} \rightarrow \mathrm{CSM}$ (CSM)

H5 Transactional Leadership (TSL) has positive effect on Crisis Management (CSM)

$\mathrm{TSL} \rightarrow \mathrm{CSM}$

Mediation Effect Hypotheses

H6 Crisis Management (CSM) mediates the relationship between Transformational Leadership (TFL) and Hotel Performance (HTP)

H7 Crisis Management (CSM) mediates the relationship between Transactional Leadership (TSL) and Hotel Performance (HTP)

$\mathrm{TFL} \rightarrow \mathrm{CSM} \rightarrow \mathrm{HTP}$

$\mathrm{TSL} \rightarrow \mathrm{CSM} \rightarrow \mathrm{HTP}$

\section{Methodology}

The methodology used involved a quantitative cross-sectional explanatory research design using a deductive approach.

\subsection{Instrument Development}

The questionnaire instrument used in this study (Table 2) was constructed from previously established measurement scales. The items under diverse constructs were measured using a five-point Likert scale (strongly disagree strongly agree). However, due to contextual differences in studies which can present significant variances, a content validity testing and a pilot study to examine the reliability of the measurement scales over conveniently recruited samples was conducted before administering the final survey (Aigbogun, Ghazali \& Razali, 2017). The validity examined the accuracy of the instrument employed in acquiring the data whereas reliability measured the internal consistency of the questionnaire items. The questionnaire items corresponding to their respective constructs were subjected to validity testing according to the comments of 5 academic experts and 2 managers of hotels in Jordan. They were given an opportunity to critique the questionnaire based on the wording, order, format and layout, understandability. Also, the experts were given options (perfect match, moderate match and poor match) to make their comments accordingly.

The validity for one item (CP9) corresponding to the crisis management indicator (crisis preparation) was $47.6 \%$, which is less than the threshold of $50 \%$. Thus, the choice was to remove this item. The validity of the questionnaire for the residual 77 items was considered a satisfactory result. Also, some adjustments were made regarding the structure and wording of the questions. Thus, the data reliability was examined by engaging twenty-five hotel managers interested in participating in the pilot study. The results of the Cronbach Alpha test for internal consistency detect that the reliability of the constructs ranged from 0.764 to 0.929 which were all above the 0.7 threshold (Hair, Ringle, \& Sarstedt, 2011).

Table 2. Instrument measures and sources

\begin{tabular}{llll}
\hline Variables & Indicators & No of items & Sources \\
\hline Transformational & Attributed (ATB) & 4 & Avolio and Bass (2004) \\
leadership & Behavior (BHV) & 4 & Avolio and Bass (2004) \\
& Motivation (MTV) & 4 & Avolio and Bass (2004) \\
& Stimulation (STM) & 4 & Avolio and Bass (2004) \\
Transactional & Considerations (CNS) & 4 & Avolio and Bass (2004) \\
leadership & Contingent Reward (CRW) & 4 & Avolio and Bass (2004) \\
& Management-by-Exception-Active (MEA) & 4 & Avolio and Bass (2004) \\
Crisis management & Management-by-Exception-Passive (MEP) & 4 & Avolio and Bass (2004) \\
& Signal Detection (CD) & 5 & Alkhawlani, et al. (2016) \\
& Preparation (CP) & 8 & Alkhawlani, et al. (2016)
\end{tabular}




$\begin{array}{llll} & \text { Containment (CC) } & 7 & \text { Alkhawlani, et al. (2016) } \\ & \text { Recovery (CR) } & 4 & \text { Alkhawlani, et al. (2016) } \\ \text { Learning (CL) } & 4 & \text { Alkhawlani, et al. (2016) } \\ & \text { Financial (FP) } & 5 & \text { Mohammed, Rashid, and Tahir (2017) } \\ & \text { Customer (CUP) } & 4 & \text { Mohammed, Rashid, and Tahir (2017) } \\ & \text { Internal Process (IP) } & 4 & \text { Mohammed, Rashid, and Tahir (2017) } \\ & \text { Learning and Growth (LG) } & 4 & \text { Mohammed, Rashid, and Tahir (2017) }\end{array}$

\subsection{Sampling}

The context of this study was the hotel sector in Jordan. The target respondents are those occupying managerial positions for three more than three years in their respective hotels (three-star to five-star). The targeting of three-star to five-star hotels is by reason of the fact that these categories of hotels are considered to have established crisis management strategies relative to one-star and two-star. The survey data were collected using a self-administered structured questionnaire via hand-to-hand administration. The sampling frame is a 2019 list of all three-star to five-star hotels obtained from the Jordan Hotel Association. The respondents were purposively recruited from the selected hotels. A total of 119 valid responses were subjected to data analysis.

\subsection{Common Method Bias}

Harman's single-factor test (Hoyle, 1995) was hired to check for common method bias. Where the results of an un-rotated EFA of all study items revealed 17 factors in total explaining 73.4638 percent of the variance.

\subsection{Data Analysis}

Partial Least Squares (PLS) technique as part of Structural Equation Modelling (SEM) was chosen because of exploratory nature of the study, was used to analyze the causal relationships between the research construct by means of a two-step approach.

\section{Results and Findings}

\subsection{Measurement Model (CFA) - Stage 1 of SEM}

Cronbach's alpha, composite reliability (CR), average variance extracted (AVE), convergent validity and discriminant validity were examined.

\subsubsection{Reliability and Convergent Validity}

The Table represents the result of reliability and convergent validity for the measurement model.

Table 3. Results of reliability and convergent validity for measurement model

\begin{tabular}{|c|c|c|c|c|c|}
\hline Construct & Item & $\begin{array}{l}\text { Factor } \\
\text { Loading }\end{array}$ & $\begin{array}{l}\text { Average } \\
\text { Variance } \\
\text { Extracted } \\
(\mathrm{AVE})^{\mathrm{a}}\end{array}$ & $\begin{array}{c}\text { Composite } \\
\text { Reliability } \\
\qquad(\mathrm{CR})^{\mathrm{b}}\end{array}$ & $\begin{array}{c}\text { Internal } \\
\text { Reliability } \\
\text { Cronbach } \\
\text { Alpha }\end{array}$ \\
\hline \multirow[t]{4}{*}{ Attributed (ATB) } & ATB1 & 0.851 & 0.692 & 0.900 & 0.852 \\
\hline & ATB2 & 0.831 & & & \\
\hline & ATB3 & 0.835 & & & \\
\hline & ATB4 & 0.811 & & & \\
\hline \multirow[t]{4}{*}{ Behavior (BHV) } & BHV1 & 0.792 & 0.700 & 0.903 & 0.857 \\
\hline & BHV2 & 0.831 & & & \\
\hline & BHV3 & 0.885 & & & \\
\hline & BHV4 & 0.835 & & & \\
\hline \multirow[t]{2}{*}{ Motivation (MTV) } & MTV1 & 0.810 & 0.697 & 0.902 & 0.855 \\
\hline & MTV2 & 0.852 & & & \\
\hline
\end{tabular}


Vol. 11, No. 4; 2020

\begin{tabular}{|c|c|c|c|c|c|}
\hline & MTV3 & 0.869 & & & \\
\hline & MTV4 & 0.807 & & & \\
\hline \multirow[t]{4}{*}{ Stimulation (STM) } & STM1 & 0.845 & 0.709 & 0.907 & 0.863 \\
\hline & STM2 & 0.857 & & & \\
\hline & STM3 & 0.822 & & & \\
\hline & STM4 & 0.843 & & & \\
\hline \multirow[t]{4}{*}{ Considerations (CNS) } & CNS1 & 0.839 & 0.719 & 0.911 & 0.870 \\
\hline & $\mathrm{CNS} 2$ & 0.875 & & & \\
\hline & CNS3 & 0.830 & & & \\
\hline & CNS4 & 0.847 & & & \\
\hline \multirow[t]{4}{*}{ Contingent Reward (CRW) } & CRW1 & 0.813 & 0.694 & 0.901 & 0.853 \\
\hline & CRW2 & 0.829 & & & \\
\hline & CRW3 & 0.845 & & & \\
\hline & CRW4 & 0.844 & & & \\
\hline \multirow{4}{*}{$\begin{array}{l}\text { Management-by-Exception-Active } \\
\text { (MEA) }\end{array}$} & MEA1 & 0.844 & 0.735 & 0.917 & 0.880 \\
\hline & MEA2 & 0.868 & & & \\
\hline & MEA3 & 0.858 & & & \\
\hline & MEA4 & 0.858 & & & \\
\hline \multirow{4}{*}{$\begin{array}{l}\text { Management-by-Exception-Passive } \\
\text { (MEP) }\end{array}$} & MEP1 & 0.848 & 0.706 & 0.905 & 0.861 \\
\hline & MEP2 & 0.883 & & & \\
\hline & MEP3 & 0.827 & & & \\
\hline & MEP4 & 0.800 & & & \\
\hline \multirow[t]{5}{*}{ Signal Detection (CD) } & CD1 & 0.847 & 0.715 & 0.926 & 0.900 \\
\hline & $\mathrm{CD} 2$ & 0.825 & & & \\
\hline & CD3 & 0.859 & & & \\
\hline & $\mathrm{CD} 4$ & 0.880 & & & \\
\hline & CD5 & 0.816 & & & \\
\hline \multirow[t]{8}{*}{ Preparation (CP) } & $\mathrm{CP} 1$ & 0.754 & 0.576 & 0.905 & 0.877 \\
\hline & $\mathrm{CP} 2$ & 0.748 & & & \\
\hline & $\mathrm{CP} 3$ & 0.745 & & & \\
\hline & CP4 & 0.741 & & & \\
\hline & CP5 & 0.767 & & & \\
\hline & $\mathrm{CP} 6$ & 0.785 & & & \\
\hline & EP7 & $0.118^{\mathrm{c}}$ & & & \\
\hline & $\mathrm{CP} 8$ & 0.773 & & & \\
\hline \multirow[t]{7}{*}{ Containment (CC) } & $\mathrm{CC} 1$ & 0.758 & 0.611 & 0.904 & 0.873 \\
\hline & $\mathrm{CC} 2$ & 0.792 & & & \\
\hline & $\mathrm{CC} 3$ & 0.810 & & & \\
\hline & $\mathrm{CC} 4$ & 0.809 & & & \\
\hline & $\mathrm{CC} 5$ & 0.789 & & & \\
\hline & CC6 & 0.728 & & & \\
\hline & EC7 & $0.157^{\mathrm{c}}$ & & & \\
\hline \multirow[t]{4}{*}{ Recovery (CR) } & CR1 & 0.756 & 0.611 & 0.863 & 0.789 \\
\hline & $\mathrm{CR} 2$ & 0.799 & & & \\
\hline & CR3 & 0.816 & & & \\
\hline & CR4 & 0.755 & & & \\
\hline
\end{tabular}




\begin{tabular}{|c|c|c|c|c|c|}
\hline \multirow[t]{4}{*}{ Learning (CL) } & CL1 & 0.724 & 0.607 & 0.860 & 0.783 \\
\hline & CL2 & 0.822 & & & \\
\hline & CL3 & 0.796 & & & \\
\hline & CL4 & 0.771 & & & \\
\hline \multirow[t]{5}{*}{ Financial (FP) } & FP1 & 0.860 & 0.714 & 0.926 & 0.900 \\
\hline & FP2 & 0.813 & & & \\
\hline & FP3 & 0.817 & & & \\
\hline & FP4 & 0.863 & & & \\
\hline & FP5 & 0.870 & & & \\
\hline \multirow[t]{4}{*}{ Customer (CUP) } & CUP1 & 0.774 & 0.636 & 0.875 & 0.809 \\
\hline & CUP2 & 0.826 & & & \\
\hline & CUP3 & 0.789 & & & \\
\hline & CUP4 & 0.800 & & & \\
\hline \multirow[t]{4}{*}{ Internal Process (IP) } & IP1 & 0.765 & 0.646 & 0.879 & 0.817 \\
\hline & IP2 & 0.792 & & & \\
\hline & IP3 & 0.851 & & & \\
\hline & IP4 & 0.804 & & & \\
\hline \multirow[t]{4}{*}{ Learning and Growth (LG) } & LG1 & 0.827 & 0.641 & 0.877 & 0.813 \\
\hline & LG2 & 0.765 & & & \\
\hline & LG3 & 0.818 & & & \\
\hline & LG4 & 0.791 & & & \\
\hline Transformational Leadership & Attributed (ATB) & 0.822 & 0.629 & 0.894 & 0.850 \\
\hline \multirow[t]{4}{*}{ (TFL) } & Behavior (BHV) & 0.816 & & & \\
\hline & Motivation (MTV) & 0.652 & & & \\
\hline & Stimulation (STM) & 0.846 & & & \\
\hline & Considerations (CNS) & 0.815 & & & \\
\hline \multirow[t]{3}{*}{ Transactional Leadership (TSL) } & Contingent Reward (CRW) & 0.780 & 0.633 & 0.838 & 0.710 \\
\hline & Management-by-Exception-Active (MEA) & 0.819 & & & \\
\hline & Management-by-Exception-Passive (MEP) & 0.788 & & & \\
\hline \multirow[t]{5}{*}{ Crisis Management (CSM) } & Signal Detection (CD) & 0.956 & 0.701 & 0.921 & 0.891 \\
\hline & Preparation $(\mathrm{CP})$ & 0.850 & & & \\
\hline & Containment (CC) & 0.789 & & & \\
\hline & Recovery (CR) & 0.733 & & & \\
\hline & Learning (CL) & 0.843 & & & \\
\hline \multirow[t]{4}{*}{ Hotel Performance (HTP) } & Financial (FP) & 0.809 & 0.649 & 0.881 & 0.820 \\
\hline & Customer (CUP) & 0.837 & & & \\
\hline & Internal Process (IP) & 0.806 & & & \\
\hline & Learning and Growth (LG) & 0.772 & & & \\
\hline
\end{tabular}

${ }^{a}$ : Average Variance Extracted $=$ (summation of the square of the factor loadings $) /\{($ summation of the square of the factor loadings) + (summation of the error variances) $\}$.

b: Composite reliability $=$ (square of the summation of the factor loadings $) /\{$ (square of the summation of the factor loadings) + (square of the summation of the error variances) $\}$.

${ }^{c}$ : Deleted/discarded item due to insufficient factor loading below threshold value 0.6. 
As shown in Table 3, the results of assessing the standardized loadings of the model's items showed that the factor loadings of CP7 and CC7 were 0.118 and 0.157 respectively. Both values were below the cut-off 0.6 (Hair et al., 2011). Thus, both items were removed from the model. The number of two deleted item was not relatively high compared to the total items in the constructs. Further, the removal does not significantly change the content of the constructs as they are conceptualized.

The revised model was once more examined to make sure whether the factor structure remained stable. As a result, the second standardized factor loadings for all items and first order constructs were above the cut-off 0.6 as recommended by Hair et al. (2006), ranged from 0.652 to 0.956 . Once the uni-dimensionality of the constructs was attained, each of the constructs was examined for their reliability by means of AVE, CR and Cronbach's alpha (Table) which revealed above the cut-off (0.5) values which ranged from 0.576 to 0.735 for AVE (Nunnally and Bernstein, 1994). The values for CR ranged from 0.838 to 0.926 which exceeded the recommended threshold of 0.6 for all constructs (Bagozzi and Yi, 1988). The Cronbach's alpha values ranged from 0.710 to 0.900 which were above the threshold of 0.7 (Nunnally and Bernstein, 1994).

\subsubsection{Discriminant Validity}

Discriminant validity was examined in three ways: i. assessing the cross loadings, ii. Fornell-Larcker Criterion and iii. HTMT Discriminant Criteria.

The results of the cross loadings of the indicators showed that an indicator's outer loading on the associated construct was greater than all of its loadings on other constructs on each item row. Furthermore, the results of the cross loading showed a difference less than 0.2 to the preferred indicator across each indicator row. These results demonstrated no discriminant validity problem (Hair et al., 2011). Also, assessing the Fornell-Larcker Criterion (Table 4) showed that the inter-correlations between the constructs ranged from 0.561 through 0.696 , which were below the threshold 0.85 (Kline 2010). Further, the analysis indicated that the value of the off-diagonal elements were smaller than the value of the square root of AVE. Therefore, it confirms that each latent construct measurement was totally discriminating to each order (Fornell \& Larcker, 1981; Hair et al., 2014) based on the Fornell-Larcker approach. Moreover, all the HTMT values of the latent constructs (Table 5) were below 0.90, ranging from 0.680 through 0.881 . Consequently, it confirms that each latent construct measurement was completely discriminating to each other (Henseler et al., 2015).

Table 4. Results of Fornell-Larcker Criterion

\begin{tabular}{lllll}
\hline & CSM & HTP & TFL & TSL \\
\hline CSM & $\mathbf{0 . 8 3 7}$ & & & \\
HTP & 0.696 & $\mathbf{0 . 8 0 6}$ & & \\
TFL & 0.590 & 0.571 & $\mathbf{0 . 7 9 3}$ & \\
TSL & 0.685 & 0.561 & 0.687 & $\mathbf{0 . 7 9 6}$ \\
\hline
\end{tabular}

Notice: Diagonals represent the square root of the average variance extracted while the other entries represent the correlations.

Table 5. Results of HTMT discriminant criteria

\begin{tabular}{lllll}
\hline & CSM & HTP & TFL & TSL \\
\hline CSM & & & & \\
HTP & 0.815 & & & \\
TFL & 0.680 & 0.686 & 0.881 & \\
TSL & 0.863 & 0.735 & & \\
\hline
\end{tabular}

\subsection{Structural Models - Stage 2 of SEM}

\subsubsection{Direct Effects of Constructs}

In the structural model, the direct effects between Transformational Leadership (TFL), Transactional Leadership (TSL), Crisis Management (CSM) and Hotel Performance (HTP) had been examined. These effects refer to 
hypotheses $\mathrm{H} 1, \mathrm{H} 2, \mathrm{H} 3, \mathrm{H} 4$ and $\mathrm{H} 5$.

The result of the hypothesized direct effects is shown in Table 6 and the structural model for testing the direct effects of the hypothesized variables is summed up in Figure 2.

Table 6. Examining results of hypothesized direct effects of the variables

\begin{tabular}{lccccccc}
\hline Path Shape & $\begin{array}{c}\text { Path } \\
\text { Coefficient }\end{array}$ & $\begin{array}{c}\text { Standard } \\
\text { Deviation }\end{array}$ & T-value & P-value & F-squared & $\begin{array}{c}\text { Effect } \\
\text { Size }\end{array}$ & $\begin{array}{c}\text { Hypothesis } \\
\text { Result }\end{array}$ \\
\hline TFL $\rightarrow$ HTP & $0.230^{*}$ & 0.106 & 2.169 & 0.030 & 0.056 & Small & H1) Supported \\
TSL $\rightarrow$ HTP & 0.036 & 0.103 & 0.348 & 0.728 & 0.001 & $\begin{array}{c}\text { No effect } \\
\text { size }\end{array}$ & H2) Rejected \\
CSM $\rightarrow$ HTP & $0.536^{* *}$ & 0.158 & 3.381 & 0.001 & 0.303 & Medium & H3) Supported \\
TFL $\rightarrow$ CSM & $0.226^{*}$ & 0.097 & 2.336 & 0.020 & 0.054 & Small & H4) Supported \\
TSL $\rightarrow$ CSM & $0.530^{* * *}$ & 0.066 & 8.014 & 0.000 & 0.295 & Medium & H5) Supported \\
\hline
\end{tabular}

$* \mathrm{p}<0.05, * * \mathrm{p}<0.01, * * * \mathrm{p}<0.001$

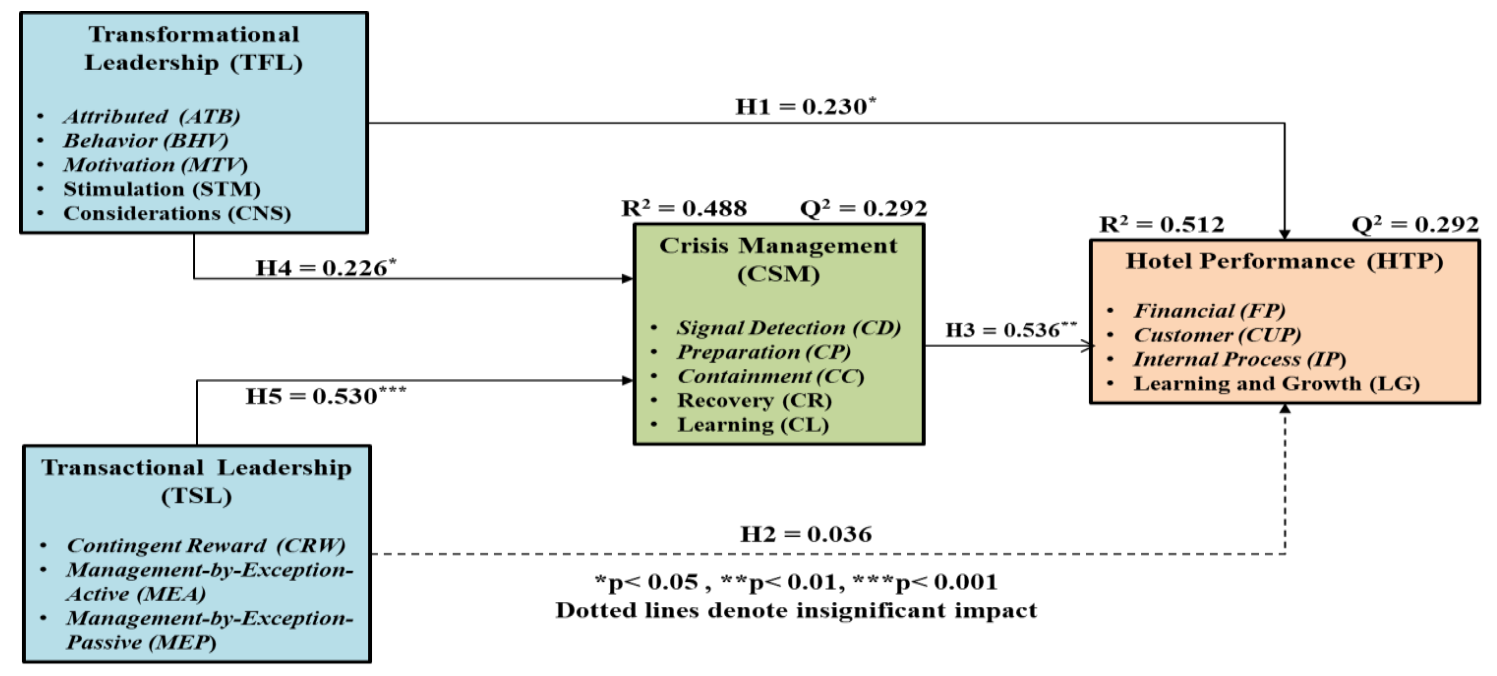

Figure 2. PLS analysis of the structural model for direct effects

The values of adjusted $\mathrm{R}^{2}$ values for Crisis Management (CSM) and Hotel Performance (HTP) have been 0.488 and 0.512 respectively. This suggests, for instance, the error variance of Hotel Performance (HTP) is almost $48.8 \%$ of the variance of Hotel Performance (HTP) itself. Additionally, 51.2\% of variations in Hotel Performance (HTP) are clarified by its three predictors. Total findings showed that the $\mathrm{R}^{2}$ values satisfy the requested for the 0.30 threshold value. The values of the predictive relevance $\left(\mathrm{Q}^{2}\right)$ for Crisis Management (CSM) and Hotel Performance (HTP) were 0.292 for both. This value is greatest than zero that refers to predictive relevance of the model as recommended by (Chin, 2010), hence, the model shows an acceptable fit and high predictive relevance.

\subsection{Mediation Effect of CSM}

Mediation analysis was used to determine the effects of crisis management mediation on the relationship between transformational leadership and transactional leadership as independent variables on hotel performance as a dependent variable. Thus, hypothesis (H6 and H7) have been examined in this part. Table 7 showed the results of examining these hypotheses with the standardized effects of different paths. 
Table 7. Results of examining mediation effects

\begin{tabular}{|c|c|c|}
\hline \multirow{2}{*}{$\begin{array}{l}\text { DV = Hotel Performance }(\mathrm{HTP}) \\
\mathrm{M}=\text { Crisis Management }(\mathrm{CSM})\end{array}$} & \multicolumn{2}{|l|}{ Independent Variables (IVs) } \\
\hline & $\begin{array}{l}\text { Transformational Leadership } \\
\text { (TFL) }\end{array}$ & Transactional Leadership (TSL) \\
\hline Total Effect of IV on DV without M & $0.351^{* * *(\text { sig:0.000) }}$ & $0.320^{* * *}($ sig: $: 0.000)$ \\
\hline Direct Effect of IV on DV with M & $0.230^{*}$ (sig:0.030) & $0.036^{\text {(sig:0.728) }}$ \\
\hline Indirect Effect of IV on DV through M & $0.121^{*(\text { sig:0.050) }}$ & $0.284^{* *(\text { sig:0.001) }}$ \\
\hline Effect of IV on M (path b) & $0.226^{*}$ (sig:0.020) & $0.530^{* * * *(\text { sig: }: 0.000)}$ \\
\hline Effect of M on DV (path c) & $0.536^{* * * *(\text { sig: }: 0.001)}$ & $0.536^{* * *(\text { sig:0.001) }}$ \\
\hline Mediation Path & $\mathrm{TFL} \rightarrow \mathrm{CSM} \rightarrow \mathrm{HTP}$ & $\mathrm{TSL} \rightarrow \mathrm{CSM} \rightarrow \mathrm{HTP}$ \\
\hline Mediation Effect & Yes & Yes \\
\hline Degree of Mediation & Partial & Full \\
\hline Hypothesis Result & H6) Supported & H7) Supported \\
\hline
\end{tabular}

$* \mathrm{p}<0.05, * * \mathrm{p}<0.01, * * * \mathrm{p}<0.001$

As revealed in Mediation analysis was used to determine the effects of crisis management mediation on the relationship between transformational leadership and transactional leadership as independent variables on hotel performance as a dependent variable. Thus, hypothesis (H6 and H7) have been examined in this part. Table 7 showed the results of examining these hypotheses with the standardized effects of different paths.

Table, Crisis Management (CSM) mediates the relationships between Transformational Leadership (TFL) and Transactional Leadership (TSL) as IVs on Hotel Performance (HTP). Hence, the hypotheses 6 and 7 have been supported.

\section{Conclusion}

The findings reveal that the direct effect (H2) of Transactional Leadership (TSL) on Hotel Performance (HTP) was not statistically significant as the p-values had been above the standard significance level of 0.05 . However, all other paths ( $\mathrm{H} 1, \mathrm{H} 3, \mathrm{H} 4$, and $\mathrm{H} 5)$ have been statistically significant as their p-values have been below the standard significance level of 0.05 . Consequently, the hypotheses H1, H3, H4, and H5 had been supported. Conversely, hypothesis $\mathrm{H} 2$ was rejected. Moreover, it was noted that the most important determinant of Hotel Performance (HTP) was Crisis Management (CSM), followed by Transformational Leadership (TFL); while Transactional Leadership (TSL) was found as the most important determinant of Crisis Management (CSM).

Furthermore, the direct effect of Transformational Leadership (TFL) as IV on Hotel Performance (HTP) as DV with the inclusion of Crisis Management (CSM) as Mediator was statistically significant at 0.05 level, thus, indicating a partial mediation. However, the results also showed that Crisis Management (CSM) mediates the relationship between Transactional Leadership (TSL) and Hotel Performance (HTP). The degree of mediation was full since the direct effect was found as statistically insignificant. The phenomenon supported the hypothesis H6 and H7 respectively.

Building on prior studies, this paper offers significant contributions to the field of organizational behaviour by introducing the role of crisis management into the hotel performance debate and establishing its mediating effect on leadership styles and hotel performance. This framework is holistic in design and it helps to improve the understanding of the intervention of crisis management strategies via the five reflective indicators of - signal detection, preparation, containment, recovery and learning. This has vital theoretical and practical implications to both researchers, hotel industry practitioners, policy makers and regulators. Theoretically, the findings offer critical 
empirical and conceptual information to the literature in an area that has received only limited attention. Empirically, the five indicators of crisis management strategy which has not been robustly tested by previous studies in the literature, has been validated in this empirical research, thus improving its confidence. Conceptually, the framework that has been tested in this paper serves as a foundation for future researchers to build upon in future research on the subject matter. Moreover, the study findings presents opportunities for hotel managers and owners to imbibe into their hotel operations, the requisite factors that has been tested in this research for improving their performance even in the midst of unwanted/unforeseen crisis events. This also helps policy makers to strengthen policies that would enforce investment in necessary capabilities in hotel management.

This research has some limitations which includes the following: It should be noted that the research was carried out within a specific industry (hotel industry), and in one country (Jordan), however, replications in other contexts would increase confidence of the research findings. This provides other researchers with an opportunity to carry out a comparative analysis with the results of the present research. Furthermore, in collecting hotel information, the present research relied on cross sectional data as well as subjective responses only. It is suggested that future researchers supplement this with a longitudinal study as well as some form of objective data as this might provide more robust information.

\section{References}

Aigbogun, O., Ghazali, Z., \& Razali, R. (2015). Resilience Attributes of Halal Logistics on the Pharmaceutical Supply Chain. Global Business and Management Research: An International Journal, 7(3), 34-43.

Aigbogun, O., Ghazali, Z., \& Razali, R. (2016). The Mediating Impact of Halal Logistics on Supply Chain Resilience: An Agency Perspective. International Review of Management and Marketing, 6(S4), 209-216.

Aigbogun, O., Ghazali, Z., \& Razali, R. (2017). The Impact of Regulatory Function on Supply Chain Resilience: Reliability of Measurement Scales. Global Business and Management Research: An International Journal, 9(1s), 524-531.

Aigbogun, O., Yassin, S. N., \& Zeeshan, S. (2013). A Model for Accelerating the Growth of Health Care Tourism in Malaysia. Journal of Business and Economics, 4(2), 169-179.

Al Hanafi, A. J. (2007). Risk Management Methods in Iraqi Banks. The Arab Gulf Studies Center, Al Basra University.

Al-Ababneh, M., \& Lockwood, A. (2010). The influence of managerial leadership style on employee job satisfaction in Jordanian resort hotels. In the 28th EuroCHRIE Annual Research Conference, Amsterdam, Netherlands.

Aldehayyat, J. S., Al Khattab, A. A., \& Anchor, J. R. (2011). The use of strategic planning tools and techniques by hotels in Jordan. Management Research Review, 34(4), 477-490

Aljuhmani, H. Y., \& Emeagwali, O. L. (2017). The Roles of Strategic Planning in Organizational Crisis Management: The Case of Jordanian Banking Sector. International Review of Management and Marketing, $7(3)$.

Alkhawlani, M. A. S., Haderi, S. M. A., bin Bohari, A. M., Ahmed, F. B., \& Rahim, N. F. A. (2016). Charisma Leadership an Important Determinant for the Crisis Management. International Journal of Business and Social Science, 7(9), 126-136.

Al-Omari, I., Ali, M., Mahmoud, R., \& JAwabreh, O. A. (2015). The Arab spring impacts on the Jordanian hotels sector. International Journal of Humanities and Social Science, 5(4), 159-177.

Alzoubi, R. H. M., \& Jaaffar, A. H. (2020). Leadership Styles, Crisis Management, and Hotel Performance: A Conceptual Perspective of the Jordanian Hotel Industry. Journal of Critical Reviews, 7(10), 556-562.

Arifah, A. R., Tariq, M., Rosliza, A. M., \& Juni, M. H. (2018). Leadership Theories in Disease Outbreak Management. International Journal of Public Health and Clinical Sciences, 5(2).

Avolio, B. J., \& Bass, B. M. (2004). Multifactor Leadership Questionnaire Third Edition Manual and Sampler Set (3rd ed.). Menlo Park, CA: Mind Garden, Inc.

Bagozzi, R. P., \& Yi, Y. (1988). On the evaluation of structural equation model. Journal of Academy of Marketing Science, 16(1), 74-94.

Chin, W. W. (2010). How to write up and report PLS analyses Handbook of partial least squares (pp. 655-690). Springer. 
Chowdhury, M. M. H., \& Quaddus, M. (2016). Supply chain readiness, response and recovery for resilience. Supply Chain Management: An International Journal, 21 (6), 709-731.

Coombs, W. T. (2015). Ongoing Crisis Communication (4th ed.). Sage, Thousand Oaks, CA.

Coombs, W. T., \& Laufer, D. (2018). Global Crisis Management-Current Research and Future Directions. Journal of International Management.

Fattah, H. M., \& Slackman, M. (2005, November). 3 Hotels Bombed in Jordan; At Least 57 Die. The New York times. Retrieved

from https://www.nytimes.com/2005/11/10/world/middleeast/3-hotels-bombed-in-jordan-at-least-57-die.html

Fornell, C., \& Larcker, D. F. (1981). Evaluating structural equation models with unobservable variables and measurement error. Journal of Marketing Research, 18(1), 39-50.

Hair Jr, J. F., Sarstedt, M., Hopkins, L., \& Kuppelwieser, V. G. (2014). Partial least squares structural equation modeling (PLS-SEM). European Business Review.

Hair, J. F., Black, W. C., Babin, B. J., Anderson, R. E., \& Tatham, R. L. (2006). Multivariate data analysis (6th ed.). United State of Amreica: Pearson prentice hall.

Hair, J. F., Ringle, C. M., \& Sarstedt, M. (2011). PLS-SEM: Indeed a silver bullet. The Journal of Marketing Theory and Practice, 19(2), 139-152.

Henseler, J., Ringle, C. M., \& Sarstedt, M. (2015). A New Criterion for Assessing Discriminant Validity in Variance-based Structural Equation Modeling. Journal of the Academy of Marketing Science, 43(1), 115-135.

Henseler, J., Ringle, C. M., \& Sinkovics, R. R. (2009). The Use of Partial Least Squares Path Modeling in International Marketing. New Challenges to International Marketing.

Hensgen, T., Desouza, K. C., \& Kraft, G. D. (2003). Games, signal detection, and processing in the context of crisis management. Journal of Contingencies and Crisis Management, 11(2), 67-77.

Hoyle, R. H. (1995). The Structural Equation Modeling Approach: Basic Concepts and Fundamental Issues. Sage, Thousand Oaks, CA.

Kharabsheh, O. H., Alias, R., \& Ismail, M. (2017). The mediating effect of organisation culture on transformational leadership and turnover intention in Jordanian public hospitals. International Journal of Business \& Management Science, 7(2), 237-260.

Kline, R. B. (2010). Principles and practice of structural equation modeling. The Guilford Press.

Laws, E., \& Prideaux, B. R. (2013). A Study of Crisis Management Strategies of Hotel Managers in the Washington, DC Metro Area. In Tourism Crises (pp. 103-118). Routledge.

Lodico, M. G., Spaulding, D. T., \& Voegtle, K. H. (2006). Methods in educational research. Jossey-Bass

Masa'deh, R. E., Alananzeh, O., Tarhini, A., \& Algudah, O. (2018). The effect of promotional mix on hotel performance during the political crisis in the Middle East. Journal of Hospitality and Tourism Technology, 9(1), 33-49.

Mitroff, I. I. (1988). Crisis management: Cutting through the confusion. MIT Sloan Management Review, 29(2), 15.

Mohammad, A. N., Idris, W. M. S., \& Moh'd AL-Ferokh, F. A. (2014). An empirical study of the moderator effect of entrepreneurial orientation on the relationship between environmental turbulence and innovation performance in five-star hotels in Jordan. International Journal of Business Administration, 5(2), 111.

MOTA. (2011). National Tourism Strategy (2011-2015). Retrieved from http://www.tourism.jo/Contents/National_StrategiesAr.aspx

Nunnally, J. C., \& Bernstein, I. H. (1994). Psychometric Theory. McGraw-Hill, New York.

Parrotto, R., \& Kim, J. (2018). Strategic leadership effectiveness in ERP implementation projects: A Qualitative Study using Multi-Grounded Theory Approach. Department of Industrial Management, Blekinge Institute of Technology, School of Management.

Ping, W., Cui, T., \& Pan, S. (2011). Strategies of Crisis Management from Contingent Perspective. 15th Pacific Asia Conference on Information Systems (PACIS 2011). AIS Electronic Library (AISel). 
Quist, A. H. (2001). A Credible Leader for Turbulent Times: Examining the Qualities Necessary for Leading into the Future. Journal of Strategic Leadership, 2, 1-12.

Ritchie, B. W. (2009). Crisis and disaster management for tourism (pp. 1-296). Channel View Publications.

Rousaki, B., \& Alcott, P. (2006). Exploring the Crisis Readiness Perceptions of Hotel managers in the UK. Tourism and Hotel Research, 7, 27-38.

Santana, G. (1999). Understanding Crisis and Crisis Management: Towards a Model. In Eco-Terrorism: Chemical and Biological Warfare Without Chemical and Biological Weapons, Proceedings of the Chemical and Biological Medical Symposium, CBMTS-Industry I, Portland, Maine-USA. Applied Science and Analysis, Inc. (pp. 285-292).

Schneider, I., \& Sönmez, S. (1999). Exploring the touristic image of Jordan. Tourism Management, 20(4), 539-542.

Spillan, J., \& Hough, M. (2003). Crisis Planning in Small Businesses: Importance, Impetus and Indifference. European Management Journal, 21, 398-407.

Tsai, C. W. (2008). Leadership style and employee's job satisfaction in international tourist hotels. In Advances in Culture, Tourism and Hospitality Research (pp. 293-332). Emerald Group Publishing Limited.

UNWTO. (2017). Al Multaqua Ballroom, Arabian Travel Market (ATM), UNWTO Commission for the Middle East. Retrieved from http://middleeast.unwto.org/event/42nd-meeting-unwto-commission-middle-east

Wahbeh, M. (2008). Risk Management in Islamic Banks. Published in the Investors Magazine. In Aljuhmani, H. Y., \& Emeagwali, O. L. (2017). The Roles of Strategic Planning in Organizational Crisis Management: The Case of Jordanian Banking Sector. International Review of Management and Marketing, 7(3).

Wetzels, M., Odekerken-Schröder, G., \& Van Oppen, C. (2009). Using PLS path modeling for assessing hierarchical construct models: guidelines and empirical illustration. MIS Quarterly, 177-195.

Yu, L., Stafford, G., \& Armoo, A. K. (2005). A Study of Crisis management Strategies of Hotel managers in the Washington, D.C. Metro Area. In E. Laws, \& B. Prideaux (Eds.), Tourism Crises: Management Responses and Theoretical Insight (2005, pp. 91-105). The Haworth Hospitality Press.

Zech, N. (2014). Stakeholder management in the Hospitality Industry - an Empirical Survey of the Status Quo. Journal of Economics and Management Research, 3, 135-151.

Zech, N. M. (2016). Crisis Management within the Hotel Industry: A Stakeholder Relationship Management Approach. Doctoral dissertation, Doctoral thesis in Management Science. University of Latvia. 